\title{
E-Learning Policy and Technology-Enhanced Flexible Curriculum Delivery in Developing Contexts: A Critical Discourse Analysis
}

\author{
Caroline Magunje and Agnes Chigona \\ Cape Peninsula University of Technology \\ Corresponding Author: cmagunje@gmail.com
}

(Submitted: 9 June 2021; Accepted: 8 November 2021)

\begin{abstract}
Most higher education institutions globally have used e-learning policies as a strategy for technology enhanced curriculum delivery. However, few universities in Zimbabwe have elearning policies, and lack of such documents to guide technology integration leads to inefficiency and hinders provision of effective support. This study highlights the role of e-learning policy through analysis of e-learning documents and statements at a university in Zimbabwe. Using critical discourse analysis, the study unpacks the discourse of e-learning at the university, to reveal underlying assumptions and beliefs of the neoliberal, elitist paradigm, veiled under

'widening access' and flexible learning. Contexts, such as the Zimbabwean higher education, sector have very specific needs, which must be considered when formulating e-learning policies to ensure effectiveness of implementation.
\end{abstract}

Keywords: e-learning, higher education, developing context,

\section{Introduction}

The 21st century has witnessed novel ways of teaching and learning (T\&L) through the integration of information and communication technologies (ICTs) in education. Globally, institutions of higher learning have diverse means of curriculum provision. The spread of ICTs has transformed $T \& L$, paving the way for new learning settings (Duan, et al., 2010). However, most higher education institutions (HEls) in developing contexts such as Zimbabwe have not yet fully capitalised on these technologies. Zimbabwe has faced a massive brain drain for more than two decades owing to unrelenting economic challenges (Nyanga, et al., 2012). Marandu and Marandu (2015) assert that this has led to the migration of professionals and higher education students in science, technology, engineering, and mathematics.

HEls in Zimbabwe have faced increasing demand for university qualifications to replace the skilled workforce, and from students wanting to improve their chances of employment beyond the country. Universities in Zimbabwe have responded by expanding enrolment through 
traditional flexible modes of curriculum provision, such as block release, parallel/evening, and weekend programmes (Kandiero, 2015).

Traditional flexible learning methods entail creating time for face-to-face intensive learning sessions for students who are normally working lifelong learners, and typically follow three modes:

i. Evening classes, commonly referred to as parallel programmes: face-to-face sessions run in the evenings; they typically mirror campus-based full-time programmes in time and duration.

ii. Block release programmes: students visit for scheduled face-to-face sessions which can run for a week or more, after which they are released to work on assignments.

iii. Weekend programmes: intensive classroom sessions during the weekend, usually from early morning to late evening.

Lifelong learners in Zimbabwe enrol in these traditional flexible modes of curriculum delivery and have to travel and find lodgings near campus. Some universities have set up offcampus centres in major cities to draw nearby students, but this means universities must incur extra costs, including rentals, instructors' travel, and subsistence costs. Embracing e-learning would lead to reduced overall costs of instruction, while increasing access, maintaining quality, and offering convenience and flexibility to students (Alkharang \& Ghinea, 2013).

Veletsianos and Houlden (2020) describe flexible education as responsive to learner and societal needs. The flexibility of online learning eliminates constraints many adult learners face, since they may attend asynchronous courses and study when it suits them (Houlden \& Veletsianos, 2019). Online learning, as an advanced mode of distance learning, increases access to education, providing improved flexibility and promoting diverse methods of interaction (Conrad, 2002; Oblinger, et al., 2005). It allows e-learning students to obtain a degree from anywhere in the world, without face-to-face interaction in the classroom (Snejana \& Veselina, 2018). Veletsianos and Houlden (2020) posit that access is not everything and promote a broader definition of flexibility - radical flexibility - which includes increasing access through multiple and hybrid modes of learning, as well as choice in curriculum and assessment that meets the needs of learners.

Such 'radical flexibility' of online learning has potential to further widen access to university programmes in Zimbabwe. Technology-enhanced flexible curriculum provision can be accessed by anyone from anywhere if they have resources that include a conducive learning environment, electricity, internet data, devices, and digital literacy skills (Duan, et al., 2010; Du Preez \& La Grange, 2020)

Although most HEls in Zimbabwe have invested heavily in ICTs, they have not fully embraced technology for curriculum delivery (Chitanana, 2012; Kabanda, 2014). Bladergroen, et al. (2012) argued that provision of ICT infrastructure in an educational setting does not necessarily lead to adoption. Rajaram and Peters (2010) expounded that without an e-learning policy, HEls face challenges in harnessing the wealth of knowledge of participants involved in implementation of e-learning. The need for the structure provided by e-learning policies was highlighted by the 
COVID-19 pandemic which broke out in 2020, forcing education institutions to resort to remote T\&L. The need for flexible education has never been more tangible (Veletsianos \& Houlden, 2020). However, most Zimbabwean HEls failed to adequately provide the much-needed flexible education, with students calling for lecturers to be trained in e-learning and for guidance (Dell \& Sawahel, 2020).

Although Zimbabwe (like many other counties in the developing context) faces challenges such as unstable electricity supply and costly internet and data, absence of a policy at university level leads to inefficiency in effort and investment and hinders effective support strategies (Chikuni, 2016). According to Chikuni and Chigona (2015), successful integration of technologies in curriculum delivery requires buy-in from the highest levels of university structures through institutional e-learning policies that articulate top management's commitment and strategic ownership.

\section{The Case Study}

The university under study is a private, church-related pan-African institution in Zimbabwe, mandated to provide quality leadership and training in Africa. It does not receive financial aid from the government. The church has offered scholarships to students from all over Africa, especially those from poor socioeconomic backgrounds. However, economic constraints have seen a reduction in scholarships (Kent, 2018). Hence, the institution has sought to embrace technology-driven flexible curriculum delivery to widen and improve access to education.

The institution was among the first HEls ratified to offer online programmes by the Zimbabwe Council for Higher Education. In a context where most universities still advocate traditional modes of flexible learning, with thousands of students' studies disrupted by COVID19 , studying this university will provide useful insights and guidelines on the importance of elearning policy documents in a developing context.

The study seeks to examine the role of e-learning policy documents in influencing the integration of technology in flexible curriculum delivery in an $\mathrm{HEl}$ in a developing context. Policies convey how and why an institution has foregrounded certain educational principles and practices (Alford, 2005). According to Chikuni and Chigona (2015: 630), 'a policy can inform good practice depending on the attitudes and views of policy actors who formulate it' .

In this study the research question is: What role does e-learning policy formulation play in the integration of technology for flexible curriculum delivery in an $\mathrm{HEl}$ in a developing context?

The study foregrounds the importance of formulating e-learning policy documents, highlighting the attitudes and views of policy actors in the integration of technology for flexible curriculum delivery for HEls in developing contexts, through analysis of a policy document and e-learning strategic plan of an $\mathrm{HEl}$ in Zimbabwe.

Using critical discourse analysis (CDA), the study provides a theoretical critique of elearning policy and related documents of the university, to highlight the interpretation of technology- enabled curriculum delivery by various actors, to show how policies propel or hinder e-learning adoption in developing contexts. According to Fairclough and Wodak (1997), in 
discourse theory, language constructors recursively shape dialogues or conversations, as well as their dimensions. The study, therefore, shows how some discourses become dominant while others are backgrounded in the policy documents, and the implications thereof (Chikuni \& Chigona, 2015).

\section{Literature Review: The Sub-Saharan African Context}

Countries with a low Human Development Index are categorised as developing nations by the United Nations Development Program (Al-Azawei, et al., 2016), and sub-Saharan Africa (SSA) falls into this category. According to the South African Institute of International Affairs, while the overall impression of ICTs in Africa is of progress at every level, the continent lags in term of internet users (SAllA, 2020). Decades ago, Saint (1995) noted increased pressure on institutions in SSA due to increased student populations in a context characterised by deteriorating infrastructure, brain drain, and diminishing financial resources. Unfortunately, the situation is the same in the 21st century. According to Kasse and Balunywa (2013), in most underdeveloped countries lack of resources (such as electricity, devices like computers, access to and high cost of internet) have hindered implementation of ICT projects. Sakala (2019) summarised Zimbabwe' s challenges in ICT integration in education as follows:

- inadequate ICT infrastructure,

- inadequate, scanty, and erratic electricity supply,

- inadequate investment capital,

- inadequate digital literacy levels, and

- inadequate ICT skills, among other socioeconomic-related issues.

Despite this, technology is still considered the best solution to challenges of access to quality higher education in SSA (Asunka, 2014). Therefore, HEls are urged to establish core technological infrastructure, such as adequate bandwidth, learning management systems, and web-conferencing systems, for efficient and effective technology-enhanced flexible curriculum delivery (Porter, 2014). However, the full benefits of e-learning can only be realised in HEls when there is effective exploitation of technologies, and e-learning platforms are carefully adopted and integrated into the curriculum delivery process, while considering local context and practice (Dagada \& Chigona, 2013; Tanye, 2017).

As noted by Alkharang and Ghinea (2013), technology-enhanced curriculum delivery was originally adopted in industrialised countries, and implementation and operation models established in these first world contexts have been set as yardsticks worldwide. However, different contexts and regions face diverse factors and hindrances to adoption of e-learning (Alkharang \& Ghinea, 2013). Chigona and Dagada (2013) state that threats to integration of technology for curriculum delivery in HEls include resistance to innovation and change by faculty, and their negative attitude to technology. For e-learning to be successful, lecturers must accept it and be willing to do so (Sukuruman, 2019). Ali and Magalhaes (2008) observed that academic staff 
presume that e-learning creates more problems than benefits; hence, their lack of knowledge leads to resistance. According to Rienties, et al. (2013), HEls should provide training and support to equip educators with skills, knowledge, and awareness of the intricate relationship between technology, pedagogy, and content knowledge.

Therefore, university leadership has to identify and establish priorities about the integration of technology in curriculum delivery, in close collaboration with members, creating a shared understanding of the potential of e-learning, resulting in less resistance and fewer challenges (Nihuka, 2013). Altinusk (2012) pointed out the need for HEl leadership to articulate the intended direction and plans of the university, to align those within the organisation with its vision. It is the role of university management to provide institutional policies and strategic plans which outline advancement and execution of the integration of technology in curriculum delivery (Altinusk, 2012).

\section{Role of E-Learning Policies}

Most universities in Zimbabwe have emphasised the role of ICTs, as evidenced by development and implementation of ICT policies (Sakala, 2019). This can be attributed to the fact that several countries in Africa - Zimbabwe included - have favourable national ICT policies in place (Njenga, 2011). However, ICT policies generally emphasise internet bandwidth, technology accessibility and availability of computers, instead of how technology is used to enhance curriculum delivery; this leads to poor integration of ICTs in T\&L, with technology ending up as a mere tool of transmission (Mostert \& Quinn, 2009). According to Sakala (2019), Zimbabwe's National ICT Policy does not sufficiently address implementation of ICTs in education, especially for HEls. Kirkwood (2014) highlighted that research in higher education has shown that decisions to invest in technology to improve curriculum delivery are frequently driven by technology, rather than by clearly defined educational goals.

Successful introduction of e-learning to support HEls requires deeper exploration and understanding, as the emphasis is not on technology but on pedagogy and context. Nihuka (2013) observed that in HEls in developing contexts, many university departments are not conversant with the potential of technologies in curriculum delivery. It is therefore imperative that HEls have an organisational management policy on e-learning, through availing required resources and establishment of administrative procedures which impact realistic pedagogical models and affect the design of e-learning (McPherson \& Nunes, 2008). HEI management must send the message that educators will be supported, through clearly designed e-learning policies and strategies (Anthonissen, 2007).

In most African countries, Zimbabwe included, national governments do not lead institutional policies (Czerniewicz \& Brown, 2009). Tanye (2017) noted how the lack of national policy to drive e-learning can result in sluggish implementation at HEls and reduced commitment from university leadership. Gatimu (2008) highlighted that policies at HEls regulate resource allocation, are useful for establishment of guidelines and protocols, and create institutional liability for action. 
In the absence of policy, universities lack a framework supporting technology use in curriculum delivery and research, which can be viewed as a challenge and hindrance to e-learning (Njenga, 2011). However, an e-learning policy does not automatically lead to adoption of technology for curriculum delivery; the way in which an e-learning policy is formulated affects how HEls operate, and how they are structured and organised (De Freitas and Oliver, 2005). An e-learning policy in a context such as Zimbabwe, with several infrastructure challenges (Sakala, 2019), must be very clear on how such issues will be addressed.

After analysing ICT in education policies in Europe and North America, Aviram and Talmi (2005: 182) developed three clusters of 'perspectives, mind frames' , which vary on how to approach integration of technology in education:

- Technocrat discourse: ICT is seen as an obligatory force that the education system must become accustomed to.

- Reformist discourse: ICT is upheld for its ability to promote the right instructions, such as constructivist and collaborative learning.

- Holistic discourse: Sociocultural context and the desired values that should steer decision-making in education are highlighted. Inclusive theories and recommendations for the education system, that do not evade discussing the theories of their rivals (unlike technocrats and reformists), are foregrounded.

Chikuni and Chigona (2015) deduced that in technocratic and reformist policies, ICTs in education are regarded as value-neutral tools that should work efficiently, regardless of context. However, 'such ideological assumptions of e-learning ignore questions on the values of education and educational goals' (Chikuni \& Chigona, 2015: 637). In contrast, holistic discourses are context conscious and aim to guide educational decision-making to formulate comprehensive and clear recommendations for the education system (Aviram \& Talmi, 2005).

Of note is the rise of neoliberal discourse in educational policies. Ball (2016) avers that global change is taking place in education policy, characterised by education reform in most countries, despite different cultural and political histories. According to Gray, et al. (2018), neoliberalism has expressions of market essentialism as an intricate phenomenon which adapts to local qualities in varied geopolitical, economic, and cultural contexts. The discourse introduces language, norms, and other business practices, and this marketisation of higher education has led to changes through the introduction of efficiency principles, with students referred to as consumers/clients (Czerniewicz, et al., 2021). This is supported by Gray, et al. (2018: 474), who noted that institutional discourses and daily language have been colonised by market-related terms.

To determine the paradigm of e-learning policy documents, this study examines those of an $\mathrm{HEl}$ in a developing context, to understand how educational goals are propelled or hindered by the attitudes and views of policy actors. According to Stevens (2003), a critical analysis of 
policy relating to education is useful, as possibilities and limitations of the document are made visible.

\section{Critical Discourse Analysis in Policy Analysis}

According to Graham (2003), CDA provides a unified theoretical framework that acts as an intermediary between text and institution, communication and structure, and discourse and society. Fairclough (2010) noted how language is reflected as a socially conditioned process, where process refers to production of the text, and interpreting the text, which is related to the practices of the society.

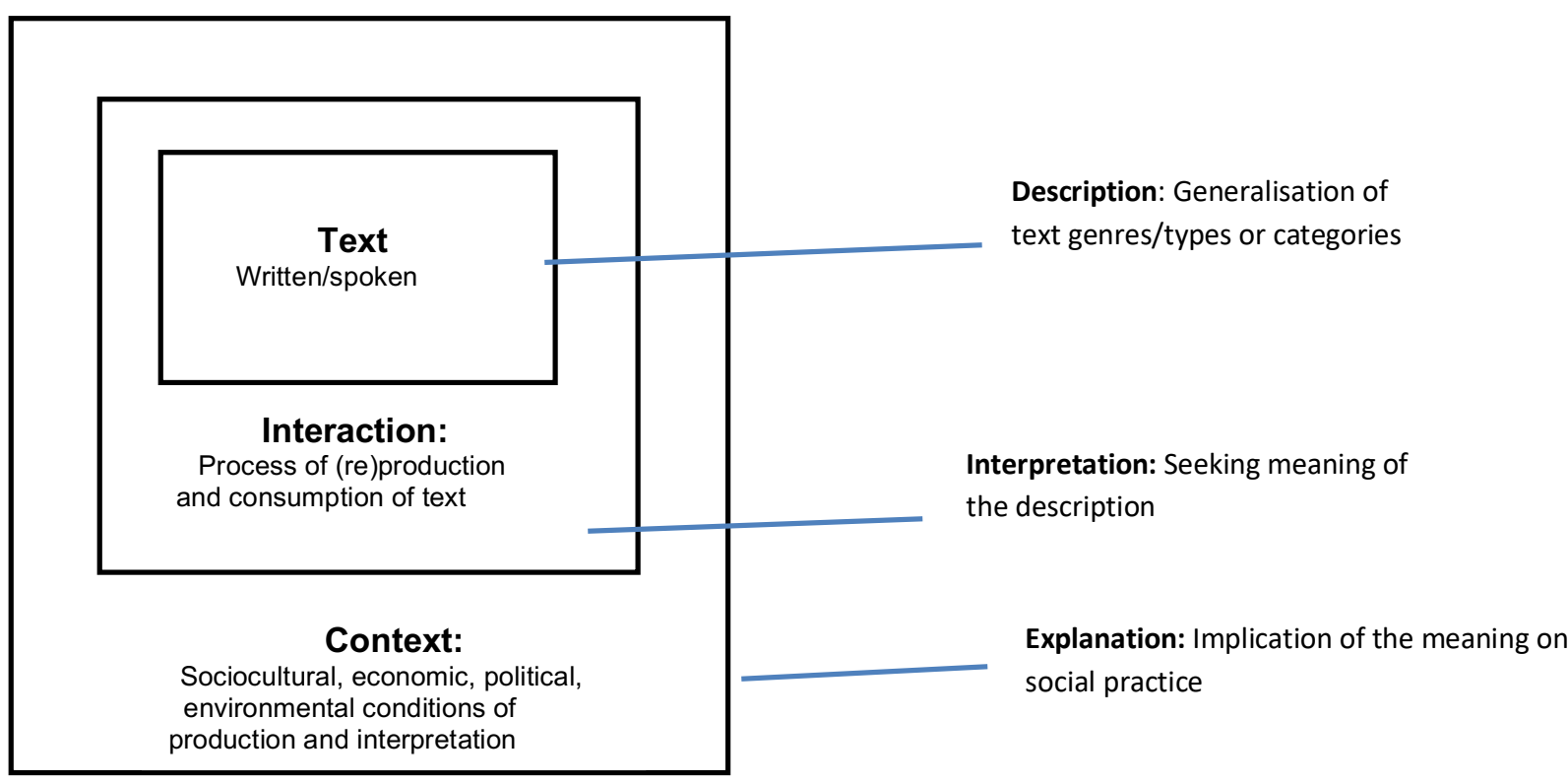

Figure 1: Fairclough' s three dimensions of discourse analysis (Fairclough, 1995)

To ensure effective analysis of policy, Fairclough (1995) developed a three-level model of CDA analysis (Figure 1), which includes language text - spoken or written, and discourse practice - text production and text interpretation. Based on the CDA model, in this study analysis of the e-learning policy and strategic plan and statements found on the institution' s social media pages will consist of three interrelated processes:

a) Text (description): Attention is given to the text, as this is used to construct identities and social relations, and broadly refers to the content of the policy itself (Bell and Stevenson, 2006; Pinto, 2011).

b) Discourse practice (interpretation): Interprets the 'relationship between the (productive and interpretative) discursive processes and the text' (Fairclough, 1995: 97).

c) Social-cultural practice: This level involves analysis of the social circumstances under which the text is formed, disseminated, consumed, and understood (Kiersay, 2011). 
The policy analysis will involve explaining the relationship between the processes and the social, cultural, environmental, and historical conditions in the context in which the university operates (Sudajit-apa, 2017).

\section{Research Methodology}

This study used document analysis to highlight the role of policy in integration of technology for curriculum delivery at an HEl. Permission to carry out the study and gain access to the data used was given by the university' s registrar after a rigorous research ethics process. Document analysis was used because in qualitative case studies this enables intensive study which produces a rich description of a single phenomenon, event, organisation, or programme (Stake, 1995). According to Yazan (2015: 118), 'documents of all types can help the researcher uncover meaning, develop understanding, and discover insights relevant to the research problem' .

Thus, analysis of documents that speak of or address e-learning at an African university provides an in-depth understanding of the phenomenon under study, thereby assisting in providing answers to the research question.

This study included analysis of official documents in the form of:

a) The E-learning Policy: Provides the university' s vision of e-learning and flexible curriculum delivery within the university context, highlights the role of essential actors in e-learning, and provides guidelines and principles of e-learning.

b) The E-learning Strategic Plan: Highlights the goals of the institution in e-learning and flexible curriculum delivery, and planned actions to achieve these.

The study also used data mining to gain an extract from the university' s official Twitter account. According to (Rambe, 2009) data mining is used to collect data on social network sites and allows access to original postings for analysis. Twitter has been used by various institutions to communicate new information (Ovadia, 2009), and the university under study has an official Twitter account managed by its marketing department, which posts at least one tweet per week. The researcher followed the university on Twitter from July 2020 to April 2021; 45 tweets were posted during this period, with four referring to online programmes. The researcher chose to use a Twitter post giving part of the institution' s Vice Chancellor' s speech during the first-year orientation week in August 2020, which was perceived to be the official position of the institution on online learning.

Through inductive coding, themes for analysis of data extracts were derived from theoretical concepts from the literature around integration of technology for flexible curriculum delivery for HEls in developing contexts. Selective extracts that address important actors in elearning in a university context as reflected by literature, that include management and academic staff, taken from the university' s E-learning Policy and E-learning Strategic Plan, were chosen for analysis as they can reveal the attitudes and views of actors who formulated the policy. CDA 
was used to analyse the texts, that represent views of reality by leading discourses at a specific place and time (Taylor, 2004). The aim was to deconstruct the meanings and language used in the documents, by analysing how issues were expressed and highlighting the standpoint of policy makers in the role of ICTs in curriculum delivery (Chikuni, 2016).

Ethical clearance for the study was granted by the Education Ethics Committee of Cape Peninsula University of Technology. The researcher obtained permission and ethical clearance from the university under study to access the policy documents. The identity of the institution under study was kept confidential, and information on the identity of the institution or individuals has been excluded.

\section{Findings}

This study sought to examine the role of an e-learning policy in influencing integration of technology in flexible curriculum delivery in an HEI in a developing context. An extract from a Twitter post as well as from the university' s policy documents are analysed using Fairclough' $s$ (1995) three levels of discourse analysis, followed by in-depth critical analysis of each, under themes derived from the literature:

i. Groundbreaker and forerunner in online learning within a developing context

ii. View of flexible learning

iii. Lecturer support in e-learning

iv. Technology as a vehicle to widen access to university programmes

v. Bringing e-learning stakeholders together

vi. The role of management in flexible curriculum provision

vii. E-learning as a cost-effective way of curriculum delivery.

\section{Groundbreaker and Forerunner in Online Learning within a Developing Context}

Despite the way online learning has revolutionised education, and the immense importance of the integration of technology and the internet in education and the impact of these changes on practice, large parts of SSA lag in e-learning (Becker, et al., 2017). Zimbabwe is an example; it has been slow in adopting technology-enhanced flexible curriculum delivery. Thus, leading in this unknown territory within such a context is a groundbreaking experience.

\section{Extract 1 - Twitter post:}

Univ . Aug 20, 2020

2/10 As the first university in Zimbabwe to be accredited to offer online programmes, you can rest assured that our university is at the forefront of the e- learning revolution in Zimbabwe and is constantly breaking new ground in this area. 
The statement in Extract 1 shows the confidence of the institution as the first university ratified to offer online programmes in Zimbabwe. The statement is persuasive and factual; it reassures prospective students of the university' s leading role in e-learning and the provision of flexible curriculum delivery. This is especially important in a developing context where online learning is viewed with suspicion and regarded as unsafe (Aljaber, 2018). At the discourse or interpretation level, the statement positions the university as a powerhouse of e-learning in Zimbabwe. The statement situates the institution as a leader and groundbreaker in e-learning, stamping its authority in online learning in the higher education fraternity of the country.

\section{Critical Analysis}

While the Twitter post is meant to foster confidence in the university among prospective students by emphasising its leading role in online learning, the statement contradicts the university' $s$ positioning in terms of the context it operates in. Zimbabwe has many challenges that hinder online learning (Sakala, 2019). According to the World Bank (2018), Zimbabwe experiences extreme inequalities; the national average poverty headcount is a meagre USD 1.90 per day. Such a socio-economic context would affect positive implementation of the policy. In Zimbabwe, this mode of delivery is discriminatory to the poor - it can only be afforded and accessed by those in urban areas who have digital devices, digital literacy, data, and electricity. The university statement implicitly identifies online learning with the elite, depicting the mode of delivery as a system that gives power only to those who can afford it, thus perpetuating inequality in the Zimbabwean context.

\section{View of Flexible Learning}

Technology-enhanced flexible curriculum delivery has provided individuals with the chance to have control and direction over their learning, thereby extending, renewing, and updating their knowledge and skills according to developments in their chosen field, without constraints of place and time (Omwenga, et al., 2005). However, educational provision goes beyond access to curriculum delivery, and requires the education programme to be 'deeply flexible across social, cultural, and material differences' (Velestianos \& Houlden, 2020: 854). Flexible curriculum delivery should therefore be defined according to context.

\section{Extract 2, from the E-learning Policy:}

The University offers the highest quality educational experience to all of its students, whether in the traditional mode of classroom instruction or in alternative teaching methodologies, such as online learning, flexible learning, and open learning that release learners from the constraints of time and place.

Extract 2 highlights the confidence of the institution in offering a quality educational experience, whatever the mode of delivery. It depicts the confidence of the institution in its degree programmes, by highlighting the statement as a fact. The statement reassures potential 
students of the institution' s commitment to high standards of learning, in technologyenhanced flexible curriculum delivery mode. It situates the university as an institution committed to provision of excellent education to lifelong learners, who are likely to have constraints around time and place. The statement acknowledges the need for flexible learning in Zimbabwe, which can be offered through technology-enhanced curriculum delivery, as evidenced by increased provision of block release and weekend programmes by HEls in the country (Kandiero, 2015).

\section{Critical Analysis}

The conception of flexible learning in the policy is a very narrow, with limited understanding of flexibility in curriculum delivery. Jones and Walters (2015) purport that flexible learning should be defined according to different situations and needs, underpinned by different discourses. Given Zimbabwe' s complex socio-economic context, the policy should have developed a definition for flexible learning that is contextualised and articulated institutionally and is relatable to the Zimbabwean and broader SSA contexts (Kirkpatrick \& Jakupec, 1997). The developing context needs flexible education 'that is responsive to learner and societal needs, available in multiple formats, through multiple delivery modes, in multiple timeframes and locations' (Veletsianos \& Houlden, 2020: 850).

\section{Technology as a Vehicle to Widen Access to University Programmes}

The demand for higher education continues to exceed supply in SSA, highlighting the need for technology to transfer skills and knowledge as an alternative to the traditional face-to-face mode (Makokha \& Mutisya, 2016). Online learning has the capacity to widen access to university programmes, since it is not constrained by (among others) issues regarding accommodation and learning space.

\section{Extract 3, from the E-learning Policy:}

The mission of Online Learning is to increase access to high-quality university courses to its customers by utilising flexible learning modes, educational technologies and emerging content delivery methods that reduce, and in some cases eliminate, the need for students to be in particular locations at set times to receive instruction.

The policy describes ICTs as a medium for reaching out to more students, who will benefit from the quality programmes offered, situating e-learning in the role of expanding the university' s sphere of influence. The university' s programmes are represented as being of such high quality that they need to be accessed by as many people as possible. The statement portrays confidence in educational technologies and their ability to provide increased flexibility to students, with ICTs as the medium of delivery. 


\section{Critical Analysis}

The university' $s$ mission through the e-learning policy is to reach more students and increase flexibility, such as for lifelong learners, through use of educational technologies, given the increase in demand for flexible programmes in Zimbabwe (Kandiero, 2015). While the mission of online learning portrays social justice in education equality, in a context such as Zimbabwe, the policy empowers working individuals who can afford the university fees and the requirements for learning through educational technologies. As a result, online learning has been described by some students in the Zimbabwean context as unaffordable, impractical, and elitist (Mukeredzi, et al., 2020). This is emphasised by the use of the term 'customer' in the policy, depicting a neoliberal discourse towards online learning.

\section{Lecturer E-Learning Support}

Resistance to adoption of technology by academic staff has been attributed to lack of support and training in integration of technology for curriculum delivery (Mostert \& Quinn, 2009; McNaught \& Kennedy, 2000). The role of the E-learning Policy is therefore to lead the structured exploitation of online pedagogical approaches in HEls, to ensure that adoption of technology is as orderly and efficient as possible (Makokha \& Mutisya, 2016). HEls should establish departments to provide support and training in technology-enhanced T\&L (Rienties, et al., 2013).

\section{Extract 4, from the E-learning Policy:}

The Continuing Education department shall exercise the following core functions:

i. oversee the development and delivery of eLearning resources for students and academic staff to enhance Continuing Education courses,

ii. identify eLearning technologies and pedagogy and recommend for implementation and,

iii. assist academic staff with course design and course development for online and webassisted courses.

The policy places assistance in technology-enhanced T\&L programmes with the department in charge of e-learning at the institution. The policy also encourages lecturers towards e-learning, as they will be provided with the support they need, highlighting the identity and engagement of the lecturer as an important element. In the statements, the role of academic staff is crucial and central. The e-learning department oversees but does not control the development of e-learning resources - the policy puts power in the hands of the lecturer, who will get to choose the technologies and pedagogies to implement. The department will empower the academic staff and students by providing support if and when needed. In broader education contexts, the role of the lecturer/academic staff is crucial in leading and facilitating learning in technology-enhanced learning. The policy statement does not emphasise technology, but rather the role of the teacher in the creation of resources and implementation of pedagogy for effective curriculum delivery. 


\section{Critical Analysis}

The text in the policy highlights the role of the lecturer and support to be provided in e-learning. Moerschell (2009) observed that resistance to technology by educators is a serious issue in HEls, and a huge hindrance in implementation of technology-enhanced curriculum delivery. Without the educators' buy-in and commitment, any strategies put in place by management may be in vain. However, most academic staff who lack experience in e-learning primarily view it as a technical 'solution' rather than pedagogical innovation (Salmon, 2005). Thus, while the policy has highlighted the support to be put in place for lecturers, it is silent on how issues of resistance will be dealt with. The policy and the E-learning Strategic Plan should highlight different strategies to counter resistance against technology-enhanced curriculum delivery. The policy also mentions establishment of an e-learning support department, positively portrayed regarding capacity building to strengthen the position of lecturers. However, success in adoption of technology for flexible curriculum delivery by lecturers is not guaranteed, as this is dependent on the way the department contextualises its approaches and strategies to meet the needs of educators at the HEl, while being cognizant of infrastructural and technological challenges in developing contexts.

\section{Bringing E-Learning Partners Together}

As a university sets out to offer technology-enhanced flexible curriculum delivery, it must ensure that every department involved in e-learning is on board. To enhance the choice of investment in tools, systems, and platforms, as well as the adoption strategies, HEls should hold consultations with all partners, including students, academics, and applicable non-academic staff, to guarantee buy-in and to evaluate readiness (Dell \& Sawahel, 2020).

\section{Extract 5, from the E-learning Policy:}

The E-learning Committee functions shall include to:

i. collaborate with other University-wide units and committee.

ii. facilitate the development and promotion of Continuing Education programmes and e-learning.

iii. support regular research on, and review of issues, challenges and opportunities that might arise with respect to new and changing learning technologies or modes of delivery, with a goal of making appropriate recommendations to the University with respect to these opportunities and challenges.

The role of the e-learning committee within the institution is that of unification, bringing university departments and units together. The statement uses words like 'collaborate' and

'facilitate' , which shows that e-learning is a process that requires teamwork. The e-learning committee ensures buy-in from various units and departments by giving them power, as they are part of the decision-making process. E-learning and educational technologies are constantly 
evolving; the policy acknowledges this and puts in place the necessary structure for advancement and progression. Through such committees, HEls secure the support of internal communities for implementation, allowing for reconciliation of diverging goals (Curran, 2004).

\section{Critical Analysis}

While the policy through the e-learning committee brings together various units, it is silent on the role of the students and how they will be supported. Universities in developing contexts such as Zimbabwe function in a complex socioeconomic environment, such that decisions made by committees are frequently resisted/not implemented (Curran, 2004). According to Veletsianos and Houlden (2020), when learners are recognised, honoured, and collaborated with, flexibility in education begins. The voice of the students in the policy could have provided holistic and realistic ways of providing the curriculum. The policy should be deliberately student-centred and clear on how students in Zimbabwe and SSA will be supported in online learning, as the most important stakeholders in any educational setting.

\section{Management Role in Online Programmes}

Leadership is crucial in effective implementation of technology-enhanced curriculum delivery; management must therefore lead from the front. Introduction of E-learning signifies substantial institutional and individual change in teaching practice, which must be carefully managed using appropriate organisational strategies, over and above the provision of technology (McPherson \& Nunes, 2008; Zentel, et al., 2004).

\section{Extract 6, from the E-learning Policy:}

The DVC shall be responsible for the following:

i. Working with faculties, institutes, and the Continuing Education Department to promote innovative ideas to improve online programme delivery.

ii. Promoting the desirable synergy among faculties/institutes, the Business Office, Registry, and the CE.

iii. Ensure academic credibility of programmes.

The policy emphasises the role of management in e-learning. The words on the role of the Deputy Vice Chancellor entail unity between management, academic units, the e-learning support unit, and other support units. The policy statements cover management buy-in, with assured support from the head of academics for integration of technology in curriculum delivery and embracing innovative ways of curriculum delivery, thereby instilling confidence in the mode of delivery within the university. The role of management in e-learning has been viewed as of paramount importance in integration of technology for curriculum delivery (Altinusk, 2012)

\section{Critical Analysis}


The policy highlights the importance of synergy between departments and various actors within the university setting. Nihuka (2013) highlighted the importance of support from management in successful integration of e-learning technologies in higher education. However, management commitment also requires a conducive environment, and Zimbabwe' s economic crises affect implementation of new technologies in most sectors (Musiyandaka, et al., 2011). The negative socio-economic context affects provision of essential resources such as data and electricity supply - elements in online learning that university management has very little influence over.

\section{E-Learning a Cost-Effective Means of Curriculum Delivery}

E-learning can be a cost-effective means of curriculum delivery, especially in Zimbabwe where most universities set up off-campus centres to draw nearby students, incurring extra costs. According to Alkharang and Ghinea (2013), e-learning reduces the overall cost of instruction, specifically those for instructors' travel and lodging, and meeting room rentals.

\section{Extract 7, from the E-learning Strategic Plan:}

The ultimate focus of online learning at university is based on fifth generation distance learning in which curriculum development and pedagogical practices become drivers of new approaches to teaching and learning through advances in information communication technologies (ICTS) which have created space for these developments. ICTS, therefore, affords University a cost-effective way to offer flexible learning to progressively more dispersed students across Africa and beyond, leading to increased enrolments.

Extract 7 gives factual information on the role of technology as a mode of delivery, foregrounding pedagogy and curriculum delivery, an important aspect in online learning. The statement emphasises progression and advancement in education and depicts the university as moving with the times. E-learning is perceived as cost-effective in delivery of the curriculum, allowing the institution to establish itself as one of the best and to reach potential students all over Africa. The statement places the institution in the discourse of other global institutions which have managed to reach out to students across the world through technology.

\section{Critical Analysis}

By alluding to new curriculum development and pedagogical practices of distance learning, the policy taps into the 21st century technology-enhanced flexible curriculum provision discourse. The university describes e-learning as a cost-effective way of curriculum delivery, which Magaji and Adelabu (2012) observed in developed economies, especially when a substantial number of students per programme is achieved. Huge numbers in online programmes might be difficult for a private institution to achieve in a country like Zimbabwe with a high level of poverty, due to high fees and the technical requirements. However, the online programme has potential to attract students from all over the world, thereby providing the required class size and reducing delivery costs. Thus, the institution might disguise the issue of widening access and social justice discourse 
for potential students within Zimbabwe, since in fact the focus of online learning is for potential students beyond Zimbabwe and even SSA.

\section{Discussion}

While the policy highlights management' $\mathrm{s}$ role in e-learning and the importance of their buyin and support in technology-enhanced flexible curriculum provision, there are also many silences and omissions. It fails, for example, to show how infrastructural issues such as electricity and internet access will be dealt with. The policy also does not foreground strategies to be used to counter resistance from educators, and nor does it include the students, who are crucial in any educational experience. The policy documents have an element of a holistic policy paradigm which acknowledges social practices of e-learning in the global context and the role of ICTs as a mode of delivery. The policy also leans towards a reformist policy paradigm, viewing ICTs as a tool that can assist the university to reach its broader academic goals. However, despite adapting to these paradigms, the policy seems detached from the context it operates in. The E-learning Policy documents take a neoliberal paradigm of an affluent, neutral, apolitical, elite university, which might be considered appropriate for a private university. However, a neoliberal discourse contradicts the university' s church-related status and its mandate to educate the future leadership of Africa. Such a position in a context like Zimbabwe or the broader SSA region perpetuates social injustice, due to disparities in access to essential infrastructure such as electricity and the internet.

The policy actors should deliberately acquaint themselves with the socio-economic contexts and potential conflicting strategies when formulating e-learning policies, to ensure effectiveness of the policy. The institution needs a conducive environment to provide effective online learning to students, wherever they may be. Thus, e-learning policy documents should be contextually predisposed, clearly elaborating the role of technology in curriculum provision and the relationship and connection between the e-learning practitioners (support department), educators, management, and students. The policy brings together various actors in the university but leaves out the most important - the student. E-learning policies must highlight the role of the student as an important actor who must also take part in the decision-making process, especially in the developing context where requirements for e-learning might not be readily accessible.

\section{Conclusion}

The study sought to establish the importance of e-learning policy document formulation, highlighting the attitudes and views of policy actors in the integration of technology for flexible curriculum delivery for HEls in developing contexts. Analysis of a policy document and the Elearning Strategic Plan of an HEl in Zimbabwe reveals the institution positively positioning itself in Zimbabwe regarding online learning, regardless of the contradictory developing context and its challenges. The view of technology-enhanced flexible learning in the policy is narrow and restrictive; it fails to develop a contextualised definition of the mode of delivery that caters for 
the needs of prospective online students in a developing context. Developing a student-centric e-learning policy will allow an HEI to develop a contextualised e-learning model that will cater for students from various backgrounds, thereby promoting equity in education and ensuring social justice. Such a policy reassures actors in the university context that e-learning is a necessary change and that they will be provided with the resources to succeed in technology-enhanced flexible curriculum provision. The study shows that the formulation of these documents is important for the provision of clear guidelines and protocols on how technology integration for flexible curriculum provision can be initiated and implemented in HEls in a developing context.

\section{Author Biographies}

Caroline Magunje is studying towards a Doctorate Degree in Education in the Faculty of Education at Cape Peninsula University of Technology (CPUT) in South Africa. Her research interest is in the integration of technology for curriculum delivery in higher education in developing contexts.

Agnes Chigona is an Associate Professor in the Faculty of Education at Cape Peninsula University of Technology (CPUT) in South Africa. She has published more than 65 research articles. She has supervised numerous masters and doctoral students. Her current research interests are ICTs in Education, Teacher resilience in the $21^{\text {st }}$ Century

\section{References}

Alford, J. 2005. Discursive patterns in ESL Policy: competing discourses in the new "Education Queensland" ESL Policy and Guidelines document. In May, S., Franken, M. \& Barnard, R. (eds.) LED 2003: Refereed Conference Proceedings of the 1st International Conference on Language, Education and Diversity. Hamilton: Wilf Malcolm Institute of Educational Research, University of Waikato.

Ali, G.E. \& Magalhaes, R., 2008. Barriers to implementing e-learning: A Kuwaiti case study. International Journal of Training and Development, 12(1): 36-53.

Alkharang, M.M. \& Ghinea, G. 2013. E-learning in higher educational institutions in Kuwait: Experiences and challenges. E-learning, 4(4): 1-6.

Al-Azawei, A., Parslow, P. \& Lundqvist, K. 2016. 'Barriers and opportunities of e-learning implementation in Iraq: A case of public universities' , International Review of Research in Open and Distance Learning, 17(5): 126-146.

Aljaber, A. 2018. E-learning policy in Saudi Arabia: Challenges and successes. Research in Comparative and International Education, 13(1): 176-194.

Altunisik, R. 2012. The Role of Leadership in the Success of e-Learning Programs: The Case of Sakarya University e-MBA Program. Procedia - Social and Behavioral Sciences, 55: 539546.

Anthonissen, C. 2003. Interaction between visual and verbal communication: Changing patterns in the printed media. In Weiss, G. \& Wodak, R. (eds.) Critical Discourse Analysis: Theory and 
Interdisciplinarity. London: Palgrave Macmillan, 297-311.

Asunka, S. 2008. Online learning in higher education in Sub-Saharan Africa: Ghanaian University students' experiences and perceptions. International Review of Research in Open and Distributed Learning, 9(3): 1-23.

Aviram, A. \& Talmi, D. 2005. The Impact of information and communication technology on education: The missing discourse between three different paradigms. E-Learning and Digital Media, 2(2): 169-191.

Ball, S.J. 2016. Neoliberal education? Confronting the slouching beast. Policy Futures in Education, 14(8): 1046-1059.

Becker, S., Cummins, M., Davis, A., Freeman, A. H., Giesinger, C. \& Ananthanarayanan, V. 2017. NMC Horizon Report: 2017. Austin, Texas

Bellblader, L. \& Stevenson, H. 2006. Process, Themes and Impact. New York: Routledge.

Bladergroen, M., Chigona, W., Bytheway, A., Cox, S., Dumas, C. \& Van Zyl, I. 2012. Educator discourses on ICT in education: A critical analysis. International Journal of Education and Development using ICT, 8(2): 107-117.

Chikuni, P.R. \& Chigona, W. 2015. Reflections on e-learning policies in HEls: A Critical Discourse Analysis (CDA) of the institutional e-learning policy in a university in South Africa. In S. Goodman, S., Human, C., Mulenga, C., Prilaid, D. \& Robertson, J. (eds). Proceedings of the 27th SAIMS annual conference: Management in Southern Africa change, challenge and opportunity. 30 August-01 September 2015. Cape Town: UCT, 630- 654.

Chikuni, P.R. 2016. The relationship between policy-making processes and e-learning policy discourses in higher education institutions in South Africa. Unpublished PhD diss., University of Cape Town, South Africa.

Chitanana, L. 2012. 'Bandwidth management in universities in Zimbabwe: Towards a responsible user base through effective policy implementation.' International Journal of Education \& Development using Information \& Communication Technology, 8(2): 62-76.

Conrad, D., 2002. Deep in the hearts of learners: Insights into the nature of online community. Journal of Distance Education, 17(1): 1-19.

Curran, C. 2004. Strategies for e-Learning in universities. Research \& Occasional Paper Series, 7(4): 1-27.

Czerniewicz, L. \& Brown, C. 2009. A study of the relationship between institutional policy, organisational culture and e-learning use in four South African universities. Computers and Education, 53(1): 121-131.

Czerniewicz, L., Mogliacci, R., Walji, S., Cliff, A., Swinnerton, B. \& Morris, N. 2021. Academics teaching and learning at the nexus: unbundling, marketisation and digitisation in higher education. Teaching in Higher Education. https://doi.org/10.1080/13562517.2021.1876019

Dagada, R. \& Chigona, A. 2013. Integration of e-learning into curriculum delivery at university level in South Africa. International Journal of Online Pedagogy and Course Design (IJOPCD), 3(1): 53-65.

Dell, S. \& Sawahel, W. 2020. African universities urged to put classes online urgently. University 
World News: Africa Edition, 20 March. Available at: https://www.universityworldnews.com/post.php?story=20200320093558384 (access: 8 March 2021)

Duan Y., He, Q., Feng, W., Li, D. \& Fu, Z. 2010. A study on e-learning take-up intention from an innovation adoption perspective: A case in China. Computers and Education, 55(1): 237246.

Du Preez, P. \& Le Grange, L., 2020. The COVID-19 pandemic, online teaching/learning, the digital divide and epistemological access. Unpublished paper.

Fairclough, N. 1995. Critical Discourse Analysis: The Critical Study of Language. London: Routledge.

Fairclough, N. \& Wodack, R. 1997. Critical discourse analysis. In Van Dijk, T. A. (ed.) Discourse as Social Interaction: Discourse Studies: A Multidisciplinary Introduction. Vol 2. Thousand Oaks, CA: Sage, 258-284.

Gatimu, K. 2009. E-learning policy making processes: an evidence-based application at Kenyatta University Marsabit Distance Learning Centre. In First Regional Conference on E-learning, Kenyatta University.

Graham, P. 2003. Critical discourse analysis and evaluative meaning: Interdisciplinarity as a critical turn. In Weiss, G. \& Wodak, R. (eds.) Critical Discourse Analysis. London: Palgrave Macmillan, 110-129

Gray, J., O' Regan, J. P. \& Wallace, C. 2018. Education and the discourse of global neoliberalism. Language and Intercultural Communication, 18(5): 471-477.

Houlden, S. \& Veletsianos, G. 2019. A posthumanist critique of flexible online learning and its "anytime anyplace" claims. British Journal of Educational Technology, 50: 1005-1018.

Jones, B. M. \& Walters, S. 2015. Flexible learning and teaching: looking beyond the binary of fulltime/part-time provision in South African Higher Education. Critical Studies in Teaching and Learning, 3(1): 61-84.

Kabanda, G. 2014. Technology affordances and diffusion for mobile connectivity and applications in Zimbabwe. International Journal of Emerging Technology and Advanced Engineering, 4(6): 13-23.

Kandiero, A. 2015. Educators' challenges and behavioural intention to adopt open educational resources: the case of Africa University, Zimbabwe. Unpublished Master's thesis, University of Cape Town, South Africa.

Kent A. 2018. Recent Trends in International Scholarships. In Dassin J., Marsh R. \& Mawer M. (eds.). International Scholarships in Higher Education. London: Palgrave Macmillan, Cham, 23-42.

Kirkpatrick, D. \& Jakupec, K.R. 1997. Flexible learning: Implications for academic practice, University of Technology, Sydney. In AARE Annual Conference, Brisbane.

Kasse, J.P. \& Balunywa, W. 2013, February. An assessment of e-learning utilization by a section of Ugandan universities: challenges, success factors and way forward. In International conference on ICT for Africa (Vol. 15). 
Kiersey, R. 2011. The Discursive Construction of Irish Early Childhood Education and Care policy: A Critical Discourse analysis. Dublin: Dublin Institute of Technology.

Kirkwood, A. 2014. Teaching and learning with technology in higher education: Blended and distance education needs "joined-up thinking" rather than technological determinism. Open Learning, 29(3): 206-221.

Magaji, S. \& Adelabu, J.S.A. 2012. 'Cost-benefit of e-learning under ODL of developing economies' . Huria: Journal of the Open University of Tanzania, 13(2): 107-122.

Makokha, G.L. \& Mutisya, D.N. 2016. Status of E-learning in public Universities in Kenya. International Review of Research in Open and Distance Learning, 17(3): 341-359.

McNaught, C. \& Kennedy, P. 2000. Staff development at RMIT: bottom-up work serviced by topdown investment and policy. A/t-J, 8(1): 4-18.

McPherson, M.A. \& Nunes, J.M. 2008. Critical issues for e-learning delivery: What may seem obvious is not always put into practice. Journal of Computer Assisted Learning, 24(5): 433445.

Moerschell, L. 2009. Resistance to technological change in academia. Current Issues in Education, 11(6): 36-39.

Mostert, M. \& Quinn, L. 2009. Using ICTs in teaching and learning: Reflections on professional development of academic. Journal of Education, 5(5): 72-84.

Mukeredzi, T., Kokutse, F. \& Dell, S. 2020. Student bodies say e-learning is unaffordable and elitist. University World News: Africa Edition, 22 April. Available at: https://www.universityworldnews.com/post.php?story=20200422075107312 (access: 22 April 2021).

Marandu E. \& Marandu E. 2015. Strategies for enhancing 21st century global literacy with Zimbabwe in mind: The 2013 global literacy rate. International Journal of Advances in Management and Economics, 4(3): 125-131.

Musiyandaka, D., Ranga, G. \& Kiwa, J. F. 2011. An analysis of factors influencing success of ICT4D projects: A case study of the schools computerisation programme in Mashonaland West Province, Zimbabwe. The Journal of Community Informatics, 9(4): 1-4.

Nihuka, K. A. 2013. Factors for effective e-learning integration in higher education in Sub-Sahara Africa. Huria - Journal of the Open University of Tanzania, 15(1): 128-145.

Njenga, J.K., 2011. eLearning adoption in Eastern and Southern African higher education institutions. Unpublished PhD diss., University of the Western Cape, South Africa.

Nyanga, T., Mpala, C. \& Chifamba, E. 2012. Brain drain: Implications for sustainable development in Zimbabwe. Journal of Sustainable Development in Africa, 14(8): 141-153.

Omwenga, E., Waema, T. \& Wagacha, P. 2005. A model for introducing and implementing elearning for delivery of educational content within the African Context. African Journal of Science and Technology, 5(1).

Ovadia, S. 2009. Internet connection exploring the potential of twitter as a research tool. Behavioral and Social Sciences Librarian, 28(4): 202-205.

Pinto, P.C. 2011. Between the lines: A critical discourse analysis of disability policy in Portugal. 
Disability Studies Quarterly, 31(3).

Porter, W., Graham, C.R., Spring, K.A.,\& Welch, K.R. 2014. Blended learning in higher education: Institutional adoption and implementation. Computers and Education, 75: 185-195.

Rajaram, A. \& Peters, D. 2010. Report to the executive management and deans meeting at University of KZN. Durban: University of KwaZulu-Natal. Unpublished Report

Rambe, P. 2009. The impact of using social networking sites on academic relations and student learning in university setting. Unpublished PhD diss., University of Cape Town, South Africa.

Rienties, B., Brouwer, N., Carbonell, K., Townsend, D., Rozendal., A., van der Loo, J., Dekker, P. \& Lygo-Baker, S. 2013. Online training of TPACK skills of higher education scholars: A crossinstitutional impact study. European Journal of Teacher Education, 36(4): 480-495.

SAIIA. 2020. Africa' s ICT infrastructure: Its present and prospects. SAllA Policy Brief No. 197. Available at: https://saiia.org.za/research/africas-ict-infrastructure-its-present-andprospects (access: 8 February 2021).

Saint, W. S. 1995. Tertiary Distance Education and Technology in Sub-Saharan Africa. Washington, DC: World Bank.

Sakala, L. 2019. Resistance to the implementation of learning management systems by lecturers in higher education in a developing country context. Cape Town: University of Cape Town. Available at: http://hdl.handle.net/11427/30345 (access: 20 July 2021)

Salmon, G. 2005. Flying not flapping: a strategic framework for e-learning and pedagogical innovation in higher education institutions. ALT-J, 13(3): 201-218.

Snejena, D. \& Veselina, N. 2018. E-learning and equal access to quality education, presentation to the $13^{\text {th }}$ International Conference on Virtual Learning

Sudajit-apa, M. 2017. Critical discourse analysis of discursive reproduction of identities in the Thai undergraduates' home for children with disabilities website project: Critical analysis of lexical selection. PASAA: Journal of Language Teaching and Learning in Thailand, 54(December): 1-28.

Sukumaran, S.D. 2019. The influence of change management and e-learning in Malaysian private higher education institutions. Pertanika Journal of Science and Technology, 27(2): 897-910.

Stevens, L. P. 2003. Reading first: A critical policy analysis. The Reading Teacher, 56(7): 662-668.

Tanye, H. A. 2017. Quality elearning in distance learning: Benefits and implications for national elearning policy in Ghana. International Journal of Multicultural and Multireligious Understanding, 4(3): 1-11.

Taylor, S. 2004. Researching educational policy and change in "new times" : Using critical discourse analysis., Journal of Education Policy, 19(4): 433-451.

Veletsianos, G. \& Houlden, S. 2020. Radical flexibility and relationality as responses to education in times of crisis. Post Digital Science and Education, 2(3): 849-862.

World Bank Group. 2018. Poverty and Equity Brief: Sub-Saharan Africa-Zimbabwe. Available at: http://data.worldbank.org/region/sun-saharan-africa (access: 2 February 2020).

Yazan, B. 2015. 'Three approaches to case study methods in education' . Qualitative Report, 20: $134-152$. 
Zentel, P., Bett, K., Meiter, D. M., Rinn, U. \& Wedekind, J. 2004. A changing process at German universities_-innovation through information and communication technologies' . Electronic Journal on e-Learning, 2(1): 237-246. 